\title{
IFNG Gene
}

National Cancer Institute

\section{Source}

National Cancer Institute. IFNG Gene. NCI Thesaurus. Code C28603.

This gene plays a role in signal transduction and immunoregulation. It is also involved in cell communication, migration, growth and proliferation. 